Jurnal IImiah Potensia, 2018, Vol. 3 (1), 43-48

\title{
PENINGKATAN KREATIVITAS ANAK MELALUI KEGIATAN BERMAIN FINGER PAINTING PADA ANAK USIA DINI KELOMPOK B PAUD AISYIYAH III KOTA BENGKULU \\ (Penelitian Tindakan Kelas Kelompok B PAUD Aisyiyah III Kota Bengkulu)
}

\author{
Levi Sartika \\ levisartika88@gmail.com \\ Nina Kurniah \\ nina kurniah@yahoo.co.id \\ Delrefi D. \\ Wembrayarli@yahoo.com
}

\begin{abstract}
The purpose of this research is to increase the creativity of children through playing finger painting activities at early childhood group B PAUD Aisyiyah III city Bengkulu. This study is a classroom action research conducted 2 cycles of the first cycle conducted 3 meetings and cycle conducted 3 meetings. The subjects of this study were 10 children consisting of $6 \mathrm{girls}$ and 4 boys. Data collection techniques in this study is observation, with data analysis techniques using the average. The results of this study prove that the improvement of children's creativity through playing finger painting can be improved through finger painting activities from the research results obtained, it is recommended for teachers to improve children's creativity by applying finger painting activities for researchers further expected research on children's creativity finger painting learning activities with other aspects
\end{abstract}

Keywords: Creativity; Finger painting

\section{PENDAHULUAN}

Undang-undang Nomor 20 Tahun 2003 Bab I ayat 14 tentang Sistem Pendidikan Nasional menyatakan bahwa pendidikan anak usia dini adalah suatu upaya pembinaan yang ditujukan kepada anak sejak lahir sampai dengan usia enam tahun yang dilakukan melalui pemberian rangsangan pendidikan untuk membantu pertumbuhan dan perkembangan jasmani dan rohani, agar anak memiliki kesiapan untuk memasuki pendidikan lebih lanjut.

Menurut Yamin dan Jamilah (2013:3) menyatakan bahwa PAUD merupakan dasar dari pendidikan anak yang selanjutnya yang penuh dengan tantangan dan sebagai jendela pembuka dunia (window of opportunity) bagi anak. Oleh karena itu, pendidikan anak usia dini saat ini sangat membutuhkan perhatian yang besar dari seluruh lapisan masyarakat, baik itu dari kebijakan pemerintah maupun dukungan dari masyarakat umum.

Pendidikan anak usia dini merupakan usia yang efektif untuk mengembangkan berbagai potensi yang dimiliki anak usia dini, salah satunya yaitu potensi kreativitas anak yang harus ditingkatkan, kerativitas yang rendah harus ditingkatkan sehingga anak memiliki kreativitas dalam kehidupan anak. Menurut Clarkl dalam Munandar (2004:18) menyatakan kreativitas merupakan pengalaman dalam mengekspresikan dan mengaktualisasikan identitas individu dalam bentuk terpadu 
antara hubungan diri sendiri, alam dan orang lain.

Munandar dalam Sujiono (2010:38) Kreativitas merupakan kemampuan yang mencerminkan kelancaran, keluwesan, dan orisinalitas dalam berfikir.

Menurut Munandar (1999:50) kreativitas adalah sebuah proses atau kemampuan yang mencerminkan kelancaran, keluwesan, keaslian, dan keoriginalitas dalam berfikir, serta kemampuan untuk mengelaborisasi (menggabungkan, memperkaya, memperinci), suatu gagasan.

Menurut Semiawan dalam Sujiono (2010:38) berpendapat bahwa kreativitas merupakan kemampuan untuk memberikan gagasan-gagasan baru dan menerapkan dalam pemecahan masalah.

Dalam mengembangakan kreativitas pada anak, dapat dilakukan berbagai kegiatan ataupun permainan yang memiliki nilai belajar pada anak. Bertujuan agar anak memperoleh banyak pengetahuan dan pengalaman melalui permainan yang ia lakukan. Semakin banyak pengalaman dan pengetahuan yang dimiliki anak, maka akan semakin memungkinkan anak untuk memanfaatkan dan menggunakan segala pengalaman dan pengetahuan tersebut untuk menerapkan aktivitas kreatif anak.

Berdasarkan pengamatan yang telah dilakukan pada saat melakukan kegiatan Magang III pada semester ganjil yaitu semester VII, pada saat pembelajaran dengan tema binatang dikelompok B dengan jumlah anak 10 orang anak.Pada saat menggambar bebas dengan pensil anak yang memiki kelancaran dan keluwesan dalam meggambar bebas dengan menggunakan pensil dilihat gambar, keaslian guru hanya 4 orang anak (30\%), sedangkan 6 orang anak (60\%) masih dibimbing oleh guru dan dilihat dari hasilnya, sudah memiliki karya sendiri dan menguraikan ide sendiri, tetapi belum mampu menciptakan bentuk yang baru, sedangkan untuk kelancaran dan keluwesan belum berkembang dengan baik, dan 6 orang anak (60\%) lainnya dikatakan belum berkembang karena dalam kegitan ini anak tidak memiliki kelancaran dan keluwesan dan dibimbimbing oleh gurunya.

Permasalahan tersebut dapat diatasi dengan kegiatan bermain finger painting. Diadakan Penelitian Tindakan Kelas yaitu dengan Peningkatan Kreativitas Anak Melalui Kegiatan Bermain Finger Painting Pada Anak Usia Dini yang jarang dilakukan sebelumnya di PAUD Aisyiyah III Kota Bengkulu pada anak kelompok B.

Menurut Witarsono dalam Suciati (2013:26) finger painting adalah melukis dengan jari, melatih pengembangan imajinasi, memperhalus kemampuan motorik halus, dan mengasah bakat seni rupa. Lebih lanjut menurut Sumanto dalam Suciati (2006:64) menyatakan bahwa finger painting adalah jenis kegiatan membuat gambar yang dilakukan dengan cara menggoreskan adonan warna (bubur warna) secara langsung dengan jari tangan secara bebas di atas bidang gambar.

diidentifikasikan, bahwa masalah yang terdapat di PAUD Aisyiyah III Kota Bengkulu yaitu masih kurangnya mengenai pembelajaran dalam rangka peningkatan kreativitas anak, kegiatan pembelajaran yang kurang bervariasi, dan rendahnya kreativitas anak.

Tujuan dalam penelitian ini untuk mendeskripsikan pelaksanaan bermain finger painting untuk meningkatkan kreativitas anak usia dini.

Untuk mendeskripsikan apakah melalui kegiatan bermain finger painting dapat meningkatkan kreativitas anak.

\section{METODE}

Jenis penelitian ini menggunakan Penelitian Penelitian Tindakan Kelas (PTK) merupakan suatu pencermatan terhadap kegiatan belajar berupa sebuah tindakan, yang sengaja dimunculkan dan terjadi 
dalam sebuah kelas secara bersama. Tindakan tersebut di berikan oleh guru atau dnegan arahan dari guru yang dilakukan oleh siswa (Arikunto dkk 2010: 3).

Penelitian tindakan kelas ini dilakukan di PAUD Aisyiyah III Kota Bengkulu, dengan subjek penelitian yaitu anak kelompok B dengan jumlah 10 orang anak tediri dari 6 orang anak perempuan dan 4 orang anak laki-laki. Penelitian ini lakukan dengan kegiatan bermain finger apinting. Penelitian ini dilakukan II siklus siklus I 3 Kali pertemuan dan siklus II dilakukan 3 kali pertemuan. Penelitian ini dilakukan selama 3 minggu dengan tahap perencanaan, pelaksanaan, pengamatan (observasi) dan refleksi. Indikator keberhasilan pada penelitian ini yaitu jika mencapai ketuntasan mencapai 75\%. Analisis pengumpulan data menggunakan rumus :

Keterangan:

$$
\mathrm{X}=\frac{\sum \mathrm{X}}{\mathrm{N}}
$$

$X=$ Nilai rata-rata

$\sum \mathrm{x}=$ Jumlah nilai semua anak

$\mathrm{N}=$ Jumlah anak

(Aqib, 2009 : 204:205)

hasil belajar siswa dikatakan berhasil jika memenuhi indikator ketuntasan minimal $75 \%$.

\section{HASIL DAN PEMBAHASAN}

Hasil

Kreativitas anak meningkat dengan kegiatan bermain finger painting. Hal ini dapat dibuktikan dari nilai rata-rata pada setiap pertemuan. Pada siklus I rata-rata yang diperoleh 2,7 dengan kriteria Kurang dan memperoleh persentase 54\%. Pada siklus II Mingkat dengan perolehan ratarata mencapai 4,193 dengan kriteria baik sekali (BS) dengan persentase 83 persen\%. Materi yang diberikan pada setiap pertemuan kegiatannya berbeda-beda dengan tema yang sama dan sub tema yang sama.

\section{Pembahasan}

Berdasarkan hasil penelitian yang telah dilakukan peneliti yang dibantu oleh teman sejawat dan dilaksanakan II Siklus dengan subjek penelitian anak-anak kelompok B PAUD Aisyiyah III Kota Bengkulu, menunjukan bahwa pembelajaran yang dilakukan dengan kegiatan bermain finger painting dapat meningkatan kreativitas anak usia dini. Hal ini sejalan dengan pendapat yang disampaikan Salim dalam Cahyati (2014:13) menyatakan bahwa finger painting (melukis dengan jari) merupakan salah satu teknik melukis dengan mengoleskan cat pada kertas yang dilakukan pada anak untuk menuangkan imajinasinya melalui lukisan yang dibuat dengan jari-jemari anak sehingga dapat menghasilkan daya cipta dalam kegiatan ini dapat melatih motoric halus dan krativitas yang dimiliki anak. Aspek yang diamati yaitu kelancaran, keluwesan, dan keaslian.

Pada hasil pengamatan yang dilakukan pada siklus pertama pada aspek proses dengan kegiatan bermain finger painting melakukan finger painting macammacam makanan menggunakan bubur warna, hasil belajar anak masih belum mencapai indikator keberhasilan. Masih banyak anak-anak mengalami kesulitan dalam bermain finger painting karna masih belum terbiasa dilakukan dan belum bisa melukis dikertas A4 masih belum keserius dalam melakukannya. Sehingga kertas yang dilukis sering sobek akibat ketidak harihatian anak dalam melakukan finger painting akan tetapi pada pertemuan selanjutnya dilakukan pengulangan kegiatan bermain finger painting.

Pada siklus I petemuan pertama anakanak masih kesulitan dalam melakukan finger painting karna masih belum terbiasa melakukan finger painting masih kesulitan dan masih belum paham cara mebuat finger painting dilihat dari Berdasarkan perolehan anak secara individu pada ketiga 
yang diamati bahwa peningkatan kreativitas anak pada siklus 1 pertemuan pertama dilihat dari kriteria menunjukan ada 8 orang yang mendapat kriteria $\mathrm{K}$ dan 1 orang yang mendapat keriteria' SK dan perlu diperbaiki kreativitas melalui finger panting pada anak usia dini artinya pada pertemuan pertama ini masih belum mencapai indikator keberhasilan pada pertemuan pertama aspek yang rendah yaitu keluwesan.

Pada pertemuan kedua pertemuan kedua dilihat dari kriteria menunjukan ada 11 orang anak yang mendapat kriteria ' $C$ ' yang mendapat kriteria adalah Chy, Ynt, Brm, Mt.a, Mt. tc, Adl, Bn, Ihm, Afdl dan 1 orang yang mendapat keriteria B' yaitu Nly.

Pada pertemuan ketiga pertemuan ketiga dilihat dari kriteria menunjukan ada 2 orang anak yang mendapat kriteria ' $\mathrm{K}$ ' Yaitu Ynt, Ihm. dan 8 orang yang mendapat keriteria $C^{\prime}$ yaitu Nyl, Mt A, Mt Tc, Bn, Afdl, Ilhm,Bn, Brm dan perlu diperbaiki kreativitas melalui finger panting pada anak usia dini.

Pada pertemuan kedua dan ketiga hampir sama dengan pertemuan pertama yaitu peningktan kreativitas anak melalui kegiatan bermain finger painting anak masih belum optimal. Namun mengalami peningkatan dari pertemuan pertama. Beberapa anak mulai baik dalam kegiatan pembelajaran finger painting. Pada pertemuan kedua dan ketiga ini anak mulai bersemangat saat melakukan kegiatan pembelajaran finger painting, anak mulai mencoba melakukan kegiatan sendiri. Namun masih ada beberapa anak yang kurang bersemangat dan menunjukkan perhatiannya dalam melakukan kegiatan pembelajaran finger painting. Oleh karena itu pada pertemuan ini guru menjelaskan dan memberikan contoh cara bermain finger panting yang lebih jelas dan rinci, lebih memotivasi, serta membimbing anak dalam melakukan kegiatan pembelajaran. Sehingga dapat mengoptimalkan peningkatan kreativitas anak. Sehingga proses anak yang dilakukan selalu ada peningkatan dan perubahan dari anak hal ini sejalan pendapat (munandar: 45-46) menyatakan bahwa proses adalah sebuah kemampuan yang mencerminkan kelancran, dan originalitas dalam berfikir, serta mampu untuk mengelabirasikan( menggabungkan, memperkaya, memperinci) suatu gagasan.

Berdasarkan pembahasan diatas dari pertemuan pertama hingga ketiga dapat disimpulkan bahwa mengalami peningkatan dengan baik dari setiap pertemuan ada perubahan yang dialami oleh anak. Dari setiap pertemuan pertama, kedua dan ketiga ada 8 orang anak mendapat kriteria $C$ (Cukup) hal ini dikarnakan keenam anak tersebut sudah mulai mengerti cara melakukan finger painting yang dijelaskan oleh peneliti. Tetapi pada siklus I dari pertemuan pertama hingga pertemuan ketiga belum mencapai indikator keberhasilan sehingga peneliti masih melanjutkan penelitian pada siklus II.

Pada siklus II pertemuan pertama kriteria menunjukan ada 1 orang yang mendapat kriteria ' $K$ ' Yaitu Ynt. dan 9 orang yang mendapat keriteria $C^{\prime}$ yaitu $\mathrm{Nyl}, \mathrm{Mt} \mathrm{A}$, Mt Tc, Bn, Afdl, Chy, Ihm, Brm, Adl . dan perlu diperbaiki kreativitas melalui finger panting pada anak usia dini dan pada pertemua kedua $\mathrm{K}$ orang anak yaitu ynt.

Pada siklus II pertemuan III anak sudah mengalami peningkatan anak yang mendapatkan kriteria BS ada 3 orang anak. 5 orang anak mendapat kriteria $C$ dan mendapat kriteria $B$ ada 2 dipertemuan ketiga ini sudah mencapai indikator ketuntasan artinya pertemuan ketiga ini sudah baik

Berdarsakan dari setiap pertemuan anak mengalami peningkatan dan pertemuan pertama pada siklus II sudah mulai mengalami perubahan pada anak Berdasarkan hasil pengamatan ini, dapat 
diketahui bahwa melalui kegiatan pembelajaran finger painting dapat meningkatkan kreativitas anak dan memberi manfaat yang sangat baik. Hal ini sesuai dengan pendapat Kurniati dalam Suarni (2015:2) manfaat finger painting yaitu meningkatkan kemampuan berpikir dan berbuat kreatif, mengembangakan kemampuan dalam mengungkapkan nilainilai estetika dengan menggambar karyakarya kreatif dan melatih otot-otot jari. Serta ketuntasan anak meningkat dengan baik yaitu mencapai $83 \%$ dan itu artinya dalam aspek kreativitas anak melalui kegiatan bermain finger painting pada anak usia dini sudah tuntas dikarenakan telah mencapai indikator kriteria penilaian $75 \%$.

Dilihat dari setiap hasil perolehan nilai rata-rata dan hasil perolehan ketuntasan klasikal anak pada setiap pertemuan siklus I, siklus II bahwa terdapat suatu peningkatan yang baik untuk anak dalam kemampuan proses kegiatannya. Berdasarkan uraian pembahasan, dapat disimpulkan bahwa melalui kegiatan pembelajaran kegiatan bermain finger painting dapat meningkatkan kreativitas pada anak.

\section{KESIMPULAN}

Berdasarkan hasil dari penelitian yang telah dilakukan pada anak kelompok B PAUD Aisyiyah III Kota Bengkulu dapat disimpulkan bahwa:

1. Melalui kegiatan bermain finger painting dapat meningkatkan kreativitas anak yang meliputi aspek yang diamati yaitu kelancaran, keluwesan, dan keaslian. Berdasarkan penleitian ini peningkatan kreativitas anak melalui finger painting dapat meningkatkan kreativitas anak dengan baik.

2. Melalui kegiatan bermain finger painting dapat meningkatan kreativitas anak. Hal ini terbukti pada ketuntasan anak secara klasikal yang telah mencapai ketuntasan dari $39,8 \%$ pada siklus I, $83 \%$ pada silus II. Sedangkan hasil rata-rata anak sebesar 4,193 dengan kriteria BS (Baik sekali). Dari hasil tersebut menunjukan bahwa kreativitas anak mengalami peningkatan antar siklusnya.

\section{DAFTAR PUSTAKA}

Aqib, 2009. Penelitian Tindakan Kelas Untuk Guru SD,SLB, dan TK. Bandung: CV Yrama Widya.

Arikunto, 2010. Penelitian Tindakan Kelas. Jakarta: Bumi Aksara.

Cahyati, Anis. 2015. Perenapan metode pemberian tugas melalui kegiatan bermain finger painting untuk meningkatkan kreativitas anak. No 1 Volume 3. PG PAUD Universitas Pendidikan Ganesa. http://ejournal.undiksha.ac.id/index. php/JJPAUD/article/view/6223/435 $\underline{9}$

Iskandar, Harris. 2015. Pedoman Penilaian PembelajaranPendidikan Anak Usia Dini. Direktor Pembinaan Pendidikan Anak Usia Dini dan Pendidikan Masyarakat Kementrian Pendidikan Kebudayaan.

Listyowati, anies. 2014. Finger Painting. Jakarta: Erlangga.

Muliawan, Jasa Unggu. 2016. Mengembangkan Imajinasidan Kreativitas Anak. Yogyakarta: Gava Media

Mutiah, Diana. 2010. Psikologi BermainAnak Usia Dini. Jakarta: Kencana.

Munandar Utami, 2009. Pengembangan KreativitasAnak Usia Dini. Jakarta: Rineka Cipta.

, 1999. Kreativitas dan Keberbakatan. Jakarta: PT Gramedia Pustaka Utama. 
Munandar. 2004. Pengembangan Kreativitas Anak Berbakat. Jakarta: Depdikbu.

Siwi, Fitriani pradani. 2013. Meningkatkan Kreativiats Anak Melalui Melukis Dengan Permainan Warna Pada Anak Kelompok B1 TK Aisiyah IVKebun DahriKota Bengkulu. Universitas Bengkulu. Skripsi.

Sujiono, Bambang. 2010. Bermain Kecerdasan KreatifBerbasis Jamak. Jakarta: PT Indeks.

Sujiono, Yuliani Nuraini. 2010. Konsep DasarPendidikan Anak UsiaDini. Jakata: PT Indeks.

Suarni, 2016. Pengaruh kegiatan finger painting berbasis teori lokomosi terhadap keterampilan motoric halus anak. No 2 Volume 4. PAUD UNIVERSITAS PENDIDIKAN GANESHA. Unduh Pada Tanggal 11 Januari 2017.

Sumanto. 2005. Pengembangan Kreativitas Seni Rupa Anak Taman KanakKanak. Jakarta: Departemen Pendidikan Nasional.

Upton, Penney. 2012. Psikologi Perkembangan. Jakarta: Erlangga.

UU RI, NO. 20 Tahun, 2003. Tentang Sistem Pendidikan Nasional

Yamin, Martenis, dan Jamilah Sabri Sanan. 2013. Panduan Pendidikan Anak Usia Dini. Jakarta: Gaung Persada. 